\title{
New flavour bars with cherry, almond and honey
}

\author{
Cristina Miguel Pintado1, Abel Veloso², Zamira Maria², Ana Silveira1', Helena Beato', \\ Luís Pinto de Andrade ${ }^{2,3}$, Fernanda Delgado ${ }^{2,3 *}$
}

${ }^{1}$ CATAA - Agro-Food Technological Support Center Association, Castelo Branco, Portugal, Zona Industrial, Rua A, 6000-459 Castelo Branco, Portugal, ${ }^{2} I P C B-E S A$ - Polytechnic Institute of Castelo Branco-School of Agriculture, Qt. ${ }^{a}$ Sr. ${ }^{a}$ Mércules Apartado 119, $6001-909$ Castelo Branco, Portugal, ${ }^{3}$ CERNAS-IPCB - Research Centre for Natural Resources, Environment and Society, Instituto Politécnico de Castelo Branco, Portugal

\section{A B S TR A C T}

Snacks are commonly eaten in western societies and, because of that, have a non-negligible effect on consumers' health. The main objective of this work was to develop and optimize a snack formulation with sweet cherry, an important crop from the Portuguese region of Beira Interior and which has a Protected Geographical Indication (PGI). The experimental design and the optimization process were based on the Response Surface Methodology. In order to achieve that, a factorial design was implemented with three factors (almond and honey content, and baking time) and five response variables (water activity, antioxidant activity, mesophilic count, flavour and texture),

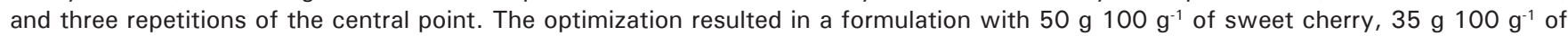

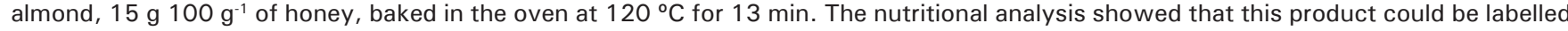
with some nutritional claims, such as "low saturated fat", "with no added sugar", "salt free" and "source of fibre".

Keywords: Almond; Honey; Response surface methodology; Snack, Sweet cherry

\section{INTRODUCTION}

The word "snack" is used, primarily, to designate a portion of a solid food or beverage, smaller than a main meal, and eaten or drunk between main meals. In fact, it is a broad word which can be used for several types of food products, fresh, processed or prepared at home. In these kinds of products, we have the snack-bars (Gatenby, 1997; Chaplin and Smith, 2011).

Snack consumption is broadly dispersed among western societies. For instance, a study implemented in UK in 2004 revealed that $90 \%$ of the respondents regularly ate snacks and an average of 410 snacks were consumed per person per year (Lloyd-Williams et al., 2008). Additionally, food ingestion between main meals could represent $25 \%$ of the total energy intake (Kant and Graubard, 2015). Because of that, snacking has a non-negligible effect on health, which could be beneficial or harmful depending on the ingredients and on the preparation method (Bucher et al., 2016; Green et al., 2017).
Sweet cherry (Prunus avium L.) is a major crop in the Portuguese Beira Interior region with a Protected Geographical Indication (PGI) (EC, 1996). Like most fresh fruits, sweet cherry is a dietary source of antioxidant compounds linked with the reduction of the incidence of oxidative related diseases like cancer and vascular diseases. Additionally, it could improve sleep, cognitive functions and help to relieve muscular pain after hard training (Usenik et al., 2008; Liu et al., 2011; Prvulovic et al., 2011; Kelley et al., 2018). The antioxidant properties of this fruit come essentially from polyphenol compounds, melatonin, carotenoids and vitamins $\mathrm{C}$ and $\mathrm{E}$. They are highly variable, depending on several factors such as cultivars, ripening stage, edaphoclimatic conditions, and cultural and postharvest practices. In fact, the antioxidant activity of sweet cherry could be as low as $3.7 \% \mathrm{DPPH}$ (1.1-diphenyl2-picrylhydrazyl) reduction or as high as $44.3 \% \mathrm{DPPH}$ reduction (Prvulovic et al., 2011; Kelley et al., 2018).

Almond (Prunus dulcis (Mill.) D. A. Webb) is also a source of antioxidant compounds (like polyphenols and $\alpha$-tocopherol), high digestible proteins and unsaturated

\footnotetext{
*Corresponding author:

Fernanda Delgado, IPCB-ESA - Polytechnic Institute of Castelo Branco-School of Agriculture, Qt. ${ }^{a}$ Sr. ${ }^{\text {a }}$ Mércules Apartado 119, $6001-909$ Castelo Branco, Portugal, CERNAS-IPCB - Research Centre for Natural Resources, Environment and Society, Instituto Politécnico de Castelo Branco, Portugal. E-mail: fdelgado@ipcb.pt
} 
fatty acids. It is linked with the reduction of the cholesterol levels, glycemic regulation and with some anti-inflammatory properties (Kamil and Chen, 2012). Almond has also a beneficial influence on the intestinal microorganisms and in colon cancer prevention (Mandalari et al., 2008). Kiat el al. (2014) mentioned $47.7 \% \mathrm{DPPH}$ reduction for the antioxidant activity of almonds.

Honey has been used as a sweetener, analgesic, antiinflammatory and antiseptic for millennia (Ferreira et al., 2009). The antiseptic properties of honey come mainly from hydrogen peroxide and from minerals like copper and iron (Ferreira et al., 2009). The antioxidant compounds from honey are essentially enzymes, like glucose-oxidase and peroxidase; vitamins, carotenoids and flavonoids (Ferreira et al., 2009). Those compounds are related with health benefits, like the protection from oxygen reactive species (Chua et al., 2013). The values found for the antioxidant activity of honey varied from 35.7 to $86.9 \%$ DPPH reduction (Baltrusaityte et al., 2007; Escuredo et al., 2013).

Response Surface Methodology (RSM) has been used as a tool for the optimization of different categories of food products, including snacks. The factors chosen to be optimized are usually related with the composition and/or preparation of the product, namely, the oven temperature and baking time (Nath and Chattopadhyay, 2007; potato-soy snacks), the levels of the ingredients, the oven temperature and the baking time (Jan et al., 2018; quinoa snacks), temperature, time, water/tea ratio and particle size (Liu et al., 2018; green tea infusion) and the steaming time, gel setting time and drying temperature (Ramesh et al., 2018; fish crackers). The response variables are mostly related with the chemical/nutritional content (Nath and Chattophadyay, 2007; Jan et al., 2018; Liu et al., 2018), physical/mechanical properties (Pardhi et al., 2017; Jan et al., 2018; Ramesh et al., 2018) and sensory characteristics (Nath and Chattopadhyay, 2007; Jan et al., 2018; Liu et al., 2018).

The main objective of this work was to optimize a snackbar formulation based exclusively in sweet cherry, almond and honey. More specifically, it was intended to find the best proportions between the ingredients and the best baking time in order to obtain a product with healthy properties, microbiological stability and consumer acceptance, while simultaneously promoting the valorisation of Portuguese regional products.

\section{MATERIALS AND METHODS}

\section{Raw materials and preparation}

The snacks were formulated exclusively with dehydrated sweet cherry (Prunus avium 'Satin'; 14.8\% of moisture content), almond (Prunus dulcis 'Ferraduel') and honey. Prior to the preparation, the almonds were toasted in the oven at $180^{\circ} \mathrm{C}$ for $15 \mathrm{~min}$. The ingredients were ground, kneaded manually and put in a silicon baking container (5.4 x $2.8 \times 1.2 \mathrm{~cm}$ ). All the formulations were cooked in the oven at $120^{\circ} \mathrm{C}$. Three independent batches were prepared for each formulation.

\section{Experimental design}

The formulation optimization was carried out through a factorial design with 3 repetitions of the central point and 3 factors: almond content $\left(\mathrm{g} 100 \mathrm{~g}^{-1}\right)\left(\mathrm{X}_{1}\right)$, honey content $\left(\mathrm{g}_{100 \mathrm{~g}^{-1}}\right)\left(\mathrm{X}_{2}\right)$ and baking time ( $\left.\mathrm{min}\right)\left(\mathrm{X}_{3}\right)$, each one with 3

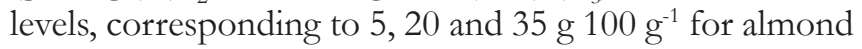

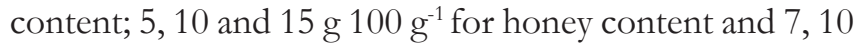
and 13 min for baking time.

The experiment consisted in a total of 11 formulations (Fig. 1) with 3 repetitions of the central point (formulations F09, F10 and F11) (Table 1) and 5 response variables: water activity $\left(\mathrm{Y}_{1}\right)$, antioxidant activity $\left(\mathrm{Y}_{2}\right)$, mesophilic count $\left(\mathrm{Y}_{3}\right)$, Flavour $\left(\mathrm{Y}_{4}\right)$ and Texture $\left(\mathrm{Y}_{5}\right)$.

\section{Qualitative evaluation of the formulations}

The water activity was determined at $25^{\circ} \mathrm{C}$ using the equipment HygroPalm (HP 23, Rotronic).

The antioxidant activity was determined using DPPH (1,1-diphenyl-2-picrylhydrazyl) as free radical, according to Brand-Williams et al. (1995). The absorbance was determined in the spectrophotometer Cintra 202 (GBC) and the results were expressed as the percentage of DPPH reduction.

The aerobic mesophilic microorganisms count was evaluated according to ISO 4833-1:2013 using Plate Count Agar as culture medium. The results were expressed as Colony Forming Units (CFU) $\mathrm{g}^{1}$ and transformed in $\log _{10}$ CFU g-1.

The hedonic evaluation of Flavour and Texture was carried out by 10 non-trained panellists with ages between 23 and 49 in a Sensory Laboratory equipped according to ISO 8589:2007/Amd 1:2014. The samples were presented randomly in Petri dishes, coded with a three digits number. The panellists were asked to rinse their palate with water after the evaluation of each sample. Flavour and Texture were evaluated in a hedonic 9-points scale (1-Dislike extremely, 5- Neither like nor dislike, 9- Like extremely). A minimum classification of 5.0 was defined as an acceptance indicator.

The energetic value and the nutritional composition were determined for the optimal formulation. Energetic value 


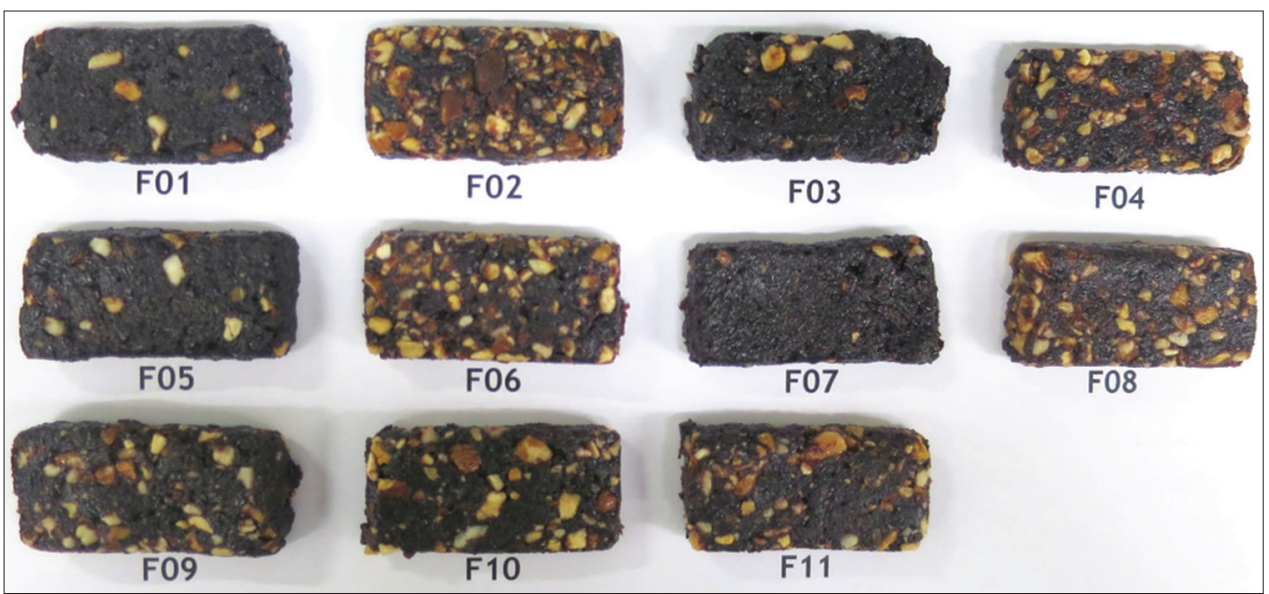

Fig 1. Formulations (F01 to F11) used for the optimization of the sweet cherry, almond and honey snack-bar carried out through a factorial design with 3 factors (almond content, honey content and baking time) and 3 repetitions of the central point (formulations F09, F10 and F11). The composition (almond and honey content) and the baking time for each formulation were, by that order, the following: F01- $5 \mathrm{~g} 100 \mathrm{~g}^{-1}, 5 \mathrm{~g}$

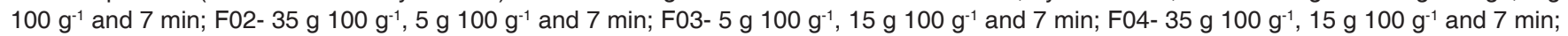

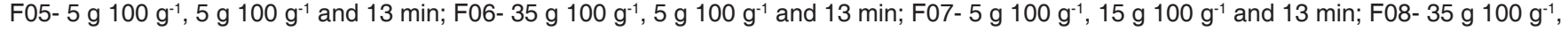

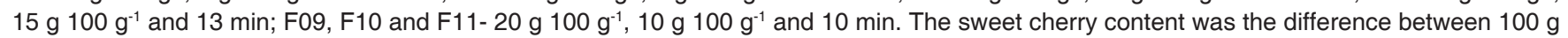
and the combined content of almond and honey.

Table 1: Decoded matrix of the factorial design of the sweet cherry, almond and honey snack-bars with 3 repetitions of the central point (formulations 9 to 11) and 3 levels for each factor

\begin{tabular}{|c|c|c|c|c|}
\hline Formulation & Sweet cherry content (g $\left.100 \mathrm{~g}^{-1}\right)$ & $\frac{X_{1}}{\text { Almond content }\left(\mathrm{g} 100 \mathrm{~g}^{-1}\right)}$ & $\frac{X_{2}}{\text { Honey content }\left({\left.\mathrm{g} 100 \mathrm{~g}^{-1}\right)}^{-1}\right.}$ & $\frac{X_{3}}{\text { Baking time }(\min )}$ \\
\hline F01 & 90 & 5 & 5 & 7 \\
\hline F02 & 60 & 35 & 5 & 7 \\
\hline F03 & 80 & 5 & 15 & 7 \\
\hline F04 & 50 & 35 & 15 & 7 \\
\hline F05 & 90 & 5 & 5 & 13 \\
\hline F06 & 60 & 35 & 5 & 13 \\
\hline F07 & 80 & 5 & 15 & 13 \\
\hline F08 & 50 & 35 & 15 & 13 \\
\hline F09 & 70 & 20 & 10 & 10 \\
\hline F10 & 70 & 20 & 10 & 10 \\
\hline $\mathrm{F} 11$ & 70 & 20 & 10 & 10 \\
\hline
\end{tabular}

calculation was based on lipid, carbohydrates, protein and fibre content (EU, 2011). The results were expressed in $\mathrm{kJ}$ and kcal per $100 \mathrm{~g}$ of product and per dose (18 g).

The ashes, protein and lipid content were determined by the method described by AOAC (2000) and the fibre content was determined by the method described by AOAC (1990). Results were expressed as g $100 \mathrm{~g}^{-1}$. Carbohydrates content was calculated by difference after the determination of moisture, lipids, fibre, protein and ashes content (EU, 2011).

Saturated fatty acids fraction was quantified after lipid extraction, followed by basic methylation, identification and quantification by gas chromatography coupled with a flame ionization detector (GC-FID 7890 A Agilent Technologies). The DB-WAXetr column (30 m, $0.25 \mathrm{~mm}$,
$0.25 \mu \mathrm{m})$, the $7683 \mathrm{~B}$ injector were used (split mode), at $260^{\circ} \mathrm{C}$.

For the sugar fraction determination, firstly the interferents were removed through a solid phase extraction column (SPE-C18, $500 \mathrm{mg} 10 \mathrm{~mL}^{-1}$ ). The sugars (glucose, fructose, sucrose, lactose and maltose) were quantified by ionic chromatography (ICS-3000, Dionex) with an electrochemical detector and the Chromeleon software. The column CarboPac PA20 ( $3 \times 150 \mathrm{~mm})$, the pre-column CarboPacGuard $(3 \times 30 \mathrm{~mm})$, a flow rate of $0.5 \mathrm{~mL} \mathrm{~min}^{-1}$ and 2 mobile phases (200 $\mathrm{mM}$ and $15 \mathrm{mM} \mathrm{NaOH}$ ) were used. The results were expressed as g $100 \mathrm{~g}^{-1}$.

Sodium was quantified after the sample microwave digestion (Ethos One, Milestone) by atomic absorption 
spectroscopy (ICE3000 Thermo Scientific) at $589 \mathrm{~nm}$. The results were expressed as mg $100 \mathrm{~g}^{-1}$.

\section{Data analysis}

The mean and the standard error of the three independent batches were determined for each response variable. Oneway analysis of variance (ANOVA) and Tukey multiple comparisons post-hoc test were carried out to determine the significant differences $(\mathrm{p}<0.05)$ between means, using the software IBM SPSS 21.

For the Response Surface Methodology (software Minitab 18), a $2^{\text {nd }}$ order polynomial model was adjusted to each response variable, as shown in Equation 1.

$$
Y_{\mathrm{k}}=\beta_{\mathrm{k} 0}+\sum_{(\mathrm{i}=1)}^{3} \beta_{\mathrm{ki}} \cdot X_{\mathrm{i}}+\sum_{(\mathrm{i}=1)}^{3} \beta_{\mathrm{kii}} \cdot X_{\mathrm{i}}^{2}+\sum_{(\mathrm{i} \neq \mathrm{j}=1)}^{3} \beta_{\mathrm{kij}} \cdot \underbrace{}_{\mathrm{i}} \cdot X_{\mathrm{j}} \text { Equation } 1
$$

Where $Y_{k}$ represents the response variable, $X_{i}$ and $X_{i}$ represent the factors, $\beta_{\mathrm{k} 0}$ represents the intercept, $\beta_{\mathrm{ki}}$ represents the linear coefficients, $\beta_{\text {kii }}$ represents the quadratic coefficients and $\beta_{\text {kij }}$ represents the interaction coefficients.

The optimization was done through the maximization of the desirability function, considering the maximization of

Table 2: Water activity, antioxidant activity and mesophilic count for the tested snack-bar ingredients, namely dehydrated sweet cherry, almond and honey

\begin{tabular}{lccc}
\hline Ingredient & $\begin{array}{c}\text { Water } \\
\text { activity }\end{array}$ & $\begin{array}{c}\text { Antioxidant } \\
\text { activity } \\
\text { (\%DPPH) }\end{array}$ & $\begin{array}{c}\text { Mesophilic } \\
\text { count }\left(\log _{10}\right. \\
\text { CFU g }\end{array}$ \\
\hline $\begin{array}{l}\text { Dehydrated } \\
\text { sweet cherry }\end{array}$ & $0.495 \pm 0.003$ & $38.4 \pm 1.0$ & $2.4 \pm 0.1$ \\
Almond & $0.491 \pm 0.002$ & $19.8 \pm 0.3$ & $3.4 \pm 0.2$ \\
Honey & $0.576 \pm 0.002$ & $5.9 \pm 0.1$ & $<1$ \\
\hline
\end{tabular}

Mean \pm standard error. $\mathrm{N}=3$ the response variables antioxidant activity, Flavour and Texture and the minimization of the response variables water activity and mesophilic count.

\section{RESULTS AND DISCUSSION}

\section{Quality of the ingredients}

All the ingredients showed a water activity lower than 0.6 (Table 2), which indicates the microbiological stability of the product (Tapia et al., 2007; Guiné et al., 2014). The water activity value for the dehydrated sweet cherry (0.495) was lower than what was described by Safe Food $360^{\circ}$ (2014). For the almond, the water activity (0.491) was similar to what was described by Du et al. (2010) and by Guiné et al. (2014). The water activity found in honey (0.576) was lower than the value described by Safe Food $360^{\circ}$ (2014) and similar to what was referred by Olaitan et al. (2007).

The antioxidant activity of the dehydrated sweet cherry (38.4\%DPPH reduction) was similar to what was found by Prvulovic et al. (2011). Nevertheless, the antioxidant activity values found for almond and honey (19.8 and 5.9\%DPPH reduction) were lower than those described previously in the literature (Baltrusaityte et al., 2007; Escuredo et al., 2013; Kiat et al., 2014).

The mesophilic count indicated a satisfactory quality for the honey $(<1 \mathrm{log})$, dehydrated sweet cherry $(2.4 \mathrm{log})$ and almond (3.4 log), according to what was defined by Gilbert et al. (2000).

\section{Effect of the factors in the quality of the formulations} Table 3 shows the mean values, the ANOVA and the Tukey post-hoc results for the response variables, for each formulation. The parameters associated with the

Table 3: Values of the factors and experimental results for the response variables from the sweet cherry, almond and honey

\begin{tabular}{|c|c|c|c|c|c|c|c|c|}
\hline \multirow[t]{3}{*}{ Cherrie formulations } & \multicolumn{3}{|c|}{ Factors } & \multicolumn{5}{|c|}{ Response variables } \\
\hline & $x_{1}$ & $X_{2}$ & $x_{3}$ & $Y_{1}$ & $Y_{2}$ & $Y_{3}$ & $Y_{4}$ & $Y_{5}$ \\
\hline & $\begin{array}{l}\text { Almond } \\
\text { content } \\
\left(\mathrm{g} 100 \mathrm{~g}^{-1}\right)\end{array}$ & $\begin{array}{l}\text { Honey } \\
\text { content } \\
\left(\mathrm{g} 100 \mathrm{~g}^{-1}\right)\end{array}$ & $\begin{array}{c}\text { Baking } \\
\text { time (min) }\end{array}$ & Water activity & $\begin{array}{c}\text { Antioxidant } \\
\text { activity } \\
\text { (\%DPPH) }\end{array}$ & $\begin{array}{l}\text { Mesophilic } \\
\text { count }\left(\log _{10}\right. \\
\text { CFU gS }\end{array}$ & Flavour & Texture \\
\hline F01 & 5 & 5 & 7 & $0.508 \pm 0.014^{a}$ & $43.3 \pm 7.9^{a}$ & $2.4 \pm 0.10^{a}$ & $5.0 \pm 0.6^{a}$ & $4.5 \pm 0.4^{\mathrm{ab}}$ \\
\hline F02 & 35 & 5 & 7 & $0.495 \pm 0.010^{a}$ & $37.4 \pm 2.5^{\mathrm{a}}$ & $2.5 \pm 0.03^{a}$ & $6.9 \pm 0.5^{a}$ & $6.8 \pm 0.4^{a}$ \\
\hline F03 & 5 & 15 & 7 & $0.503 \pm 0.012^{a}$ & $33.5 \pm 4.0^{\mathrm{a}}$ & $2.4 \pm 0.08^{a}$ & $4.9 \pm 0.5^{a}$ & $4.7 \pm 0.5^{\mathrm{ab}}$ \\
\hline F04 & 35 & 15 & 7 & $0.495 \pm 0.008^{a}$ & $34.0 \pm 3.0^{\mathrm{a}}$ & $2.5 \pm 0.15^{\mathrm{a}}$ & $6.5 \pm 0.5^{a}$ & $6.1 \pm 0.5^{\mathrm{ab}}$ \\
\hline F05 & 5 & 5 & 13 & $0.498 \pm 0.006^{a}$ & $45.6 \pm 2.0^{\mathrm{a}}$ & $2.5 \pm 0.01^{a}$ & $5.0 \pm 0.7^{a}$ & $3.8 \pm 0.6^{b}$ \\
\hline F06 & 35 & 5 & 13 & $0.479 \pm 0.013^{a}$ & $44.0 \pm 1.8^{\mathrm{a}}$ & $2.3 \pm 0.07^{a}$ & $6.0 \pm 0.5^{a}$ & $5.9 \pm 0.6^{\mathrm{ab}}$ \\
\hline F07 & 5 & 15 & 13 & $0.487 \pm 0.010^{a}$ & $45.3 \pm 11.2^{\mathrm{a}}$ & $2.3 \pm 0.13^{a}$ & $4.8 \pm 0.6^{a}$ & $4.0 \pm 0.5^{b}$ \\
\hline F08 & 35 & 15 & 13 & $0.467 \pm 0.008^{a}$ & $38.1 \pm 5.0^{\mathrm{a}}$ & $2.5 \pm 0.12^{\mathrm{a}}$ & $6.6 \pm 0.4^{a}$ & $6.8 \pm 0.4^{a}$ \\
\hline F09 & 20 & 10 & 10 & $0.481 \pm 0.013^{a}$ & $38.7 \pm 7.5^{\mathrm{a}}$ & $2.6 \pm 0.14^{a}$ & $6.1 \pm 0.6^{a}$ & $6.1 \pm 0.5^{\mathrm{ab}}$ \\
\hline F10 & 20 & 10 & 10 & $0.486 \pm 0.012^{\mathrm{a}}$ & $42.5 \pm 3.2^{\mathrm{a}}$ & $2.5 \pm 0.06^{a}$ & $6.0 \pm 0.6^{a}$ & $5.3 \pm 0.7^{\mathrm{ab}}$ \\
\hline $\mathrm{F} 11$ & 20 & 10 & 10 & $0.486 \pm 0.006^{a}$ & $40.0 \pm 4.4^{a}$ & $2.6 \pm 0.01^{a}$ & $6.2 \pm 0.6^{a}$ & $6.2 \pm 0.5^{\mathrm{ab}}$ \\
\hline
\end{tabular}
snack-bar factorial design with 3 repetitions of the central point (formulations F09 to F11)

Results presented as mean \pm standard error. Different letters in the same column indicate statistical differences at $P<0.05$. 
Table 4: Estimated regression coefficients from the second order polynomial model adjustment to each one of the response variables used for the optimization of the sweet cherry, almond and honey snack-bar

\begin{tabular}{|c|c|c|c|c|c|}
\hline & $\frac{Y_{1}}{\text { Water activity }}$ & $\frac{Y_{2}}{\text { Antioxidant activity (\%DPPH) }}$ & $\begin{array}{c}Y_{3} \\
\text { Mesophilic count }\left(\log _{10} \mathrm{CFU} \mathrm{g} \mathrm{g}^{-1}\right)\end{array}$ & $\frac{Y_{4}}{\text { Flavour }}$ & $\frac{Y_{5}}{\text { Texture }}$ \\
\hline Constant & $0.52^{* \star *}$ & $40.90^{*}$ & $2.39^{* * *}$ & $5.30 * *$ & $5.92^{*}$ \\
\hline $\mathrm{X}_{1}$ Almond content & $-0.0014^{*}$ & 0.011 & 0.028 & $0.13^{*}$ & 0.14 \\
\hline $\mathrm{X}_{2}$ Honey content & 0.00067 & -1.1 & -0.018 & -0.094 & -0.11 \\
\hline $\mathrm{X}_{3}$ Baking time & -0.00042 & 0.65 & -0.0013 & -0.074 & -0.27 \\
\hline $\mathrm{X}_{11}$ & $0.000033^{*}$ & -0.0011 & -0.00063 & -0.0017 & -0.0024 \\
\hline$x_{22}$ & ne & ne & ne & ne & ne \\
\hline$X_{33}$ & ne & ne & ne & ne & ne \\
\hline$x_{12}$ & 0.000006 & 0.0013 & 0.00052 & 0.00083 & -0.00033 \\
\hline$X_{13}$ & -0.000050 & -0.0098 & -0.00057 & -0.0019 & 0.0033 \\
\hline$X_{23}$ & -0.00015 & 0.057 & 0.00050 & 0.0075 & 0.013 \\
\hline $\mathrm{R}_{2}$ & 0.9858 & 0.8635 & 0.7674 & 0.9703 & 0.9302 \\
\hline Lack of fit & $n s$ & $n s$ & $n s$ & ns & $n s$ \\
\hline
\end{tabular}

adjustment of the second order polynomial models to the experimental data are shown in Table 4.

The $\mathrm{R}^{2}$ was higher than 0.7 and the lack of fit was not significant ( $\mathrm{p} \geq 0.05$ ) for the tested models, showing a good adjustment to the experimental data and a good ability of this models to represent them (Jan et al., 2018).

The mean values of the water activity are comprised between 0.467 (F08) and 0.508 (F01), which indicates conditions that inhibit microbial growth (Schmidt and Fontana, 2007; Safe Food $\left.360^{\circ}, 2014\right)$. The almond content (both linear and quadratic) was the only factor that showed a significant and negative effect $(\mathrm{p}<0.05)$ in water activity (Table 4$)$.

There were no significant differences $(\mathrm{p} \geq 0.05)$ between the antioxidant activity of the different formulations. The mean values from this response variable were comprised between $33.5 \% \mathrm{DPPH}$ reduction (F03) and $45.3 \% \mathrm{DPPH}$ reduction (F07) (Table 3) and are not far from the antioxidant activity of the dehydrated sweet cherry (38.4\% DPPH reduction), which was the main ingredient in all formulations.

Regarding mesophilic count, there were no statistical differences $(\mathrm{p} \geq 0.05)$ among formulations. The values found were between $2.3 \log$ (F06 and F07) and $2.6 \log$ (F09 and F11), highlighting a satisfactory microbial quality of product (Gilbert et al., 2000).

No statistical differences were found $(\mathrm{p} \geq 0.05)$ in the Flavour between formulations. The Flavour mean classifications were comprised between 4.8 (F07) and 6.9 (F02) (Table 3). The almond content had a significant positive effect $(\mathrm{p}<0.05)$ in Flavour (Table 4$)$.

Texture was the only studied response variable with significant differences $(p<0.05)$ between formulations. In
Table 5: Model validation: predicted and experimental values of the response variables from the optimization of the sweet cherry, almond and honey snack-bar

\begin{tabular}{|c|c|c|c|}
\hline Response variable & & Predicted & Experimental \\
\hline$Y_{1} \quad$ Water activity & & 0.467 & 0.467 \\
\hline$Y_{2}$ Antioxidant activity & $\begin{array}{l}\text { (\%DPPH } \\
\text { reduction) }\end{array}$ & 39.5 & 38.1 \\
\hline$Y_{3}$ Mesophilic count & $\left.\left(\log _{10} \text { CFU g g }\right)^{-1}\right)$ & 2.4 & 2.5 \\
\hline$Y_{4} \quad$ Flavour & (points) & 6.5 & 6.6 \\
\hline$Y_{5}$ Texture & (points) & 6.6 & 6.8 \\
\hline
\end{tabular}

fact, F02 and F08 showed higher Texture classifications (6.8 for both formulations) than F05 and F07 (3.8 and 4.0, respectively) (Table 3).

There were four formulations that had a lower classification than the minimum defined for sensorial acceptance (i.e. 5.0 points) in, at least, one of the two sensory descriptors (Flavour and Texture). Those formulations were the F01, with 4.5 points in Texture; F03, with 4.9 points in Flavour and 4.7 points in Texture; F05, with 3.8 points in Texture, and F07 with 4.8 points in Flavour and 4.0 points in Texture. Additionally, the lowest almond content

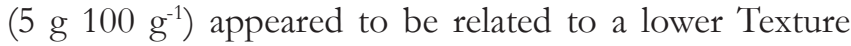
classification, which might be explained by the crunchy sensation given by the toasted almond. Moreover, the adjusted model has indicated that the almond content had a significant effect $(\mathrm{p}<0.05)$ in the water activity and in the Flavour.

The simultaneous optimization of the response variables, performed by the maximization of the desirability function, showed the following values for, respectively, the almond content, the honey content and the baking time at $120^{\circ} \mathrm{C}$ :

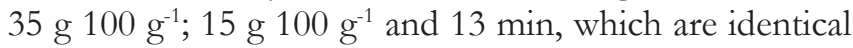
to the F08 formulation. This result may indicate that, in a future attempt, the variation amplitude of the factors in study should be increased. 
Table 6: Energy value and nutritional content of the optimized formulation of the sweet cherry, almond and honey snack-bar

\begin{tabular}{|c|c|c|c|}
\hline & \multirow[t]{2}{*}{ Units } & \multicolumn{2}{|c|}{ Nutrient content ${ }^{(a)}$} \\
\hline & & $100 \mathrm{~g}$ & Dose (18 g) \\
\hline Energy value & $\begin{array}{l}\text { kcal } \\
\text { kJ }\end{array}$ & $\begin{array}{c}430.4 \pm 4.3(21.5 \%) \\
1810.2 \pm 17.1(21.5 \%)\end{array}$ & $\begin{array}{c}77.5 \pm 0.8(3.9 \%) \\
325.8 \pm 3.1(3.9 \%)\end{array}$ \\
\hline Water & g & $9.5 \pm 0.3$ & $1.7 \pm 0.1$ \\
\hline Fat & g & $16.8 \pm 1.0(24.0 \%)$ & $3.0 \pm 0.2(4.3 \%)$ \\
\hline Saturated fatty acids & $g$ & $1.5 \pm 0.1(7.5 \%)$ & $0.27 \pm 0.02(1.4 \%)$ \\
\hline Carbohydrates & g & $58.2 \pm 1.4(18.2 \%)$ & $10.48 \pm 0.24(3.3 \%)$ \\
\hline Total sugars & g & $40.9 \pm 1.3$ & $7.4 \pm 0.2$ \\
\hline Fibre & $g$ & $3.9 \pm 0.5(15.1 \%)$ & $0.7 \pm 0.1(2.7 \%)$ \\
\hline Protein & g & $9.6 \pm 0.3(17.5 \%)$ & $1.73 \pm 0.05(3.2 \%)$ \\
\hline Ashes & $g$ & $1.97 \pm 0.03$ & $0.35 \pm 0.01$ \\
\hline Sodium & $\mathrm{mg}$ & $0.68 \pm 0.05(0.3 \%)$ & $0.12 \pm 0.01(0.1 \%)$ \\
\hline
\end{tabular}

(a)The percentage of the daily recommended intake (DRI) of the nutrient which is satisfied by the ingestion of a $100 \mathrm{~g}$ portion of the snack or one snack (18 $\mathrm{g}$ ) is indicated between parentheses. These values were determined considering a reference daily energy intake of $2000 \mathrm{kcal}$

On the other hand, the values predicted by the model for the response variables of F08 formulation and the values obtained experimentally were similar (Table 5) which was a good indicator of the reliability of the optimization method.

Finally, the optimal formulation presented a water activity that ensures the microbial stability (Tapia et al., 2007), a mesophilic count that indicates a satisfactory microbial quality (Gilbert et al., 2000) and sensory classification for Flavour and Texture above the minimum (5.0 points) defined for the sensorial acceptance of the product.

\section{Nutritional composition of the optimized formulation} The optimized formulation was prepared with $50 \mathrm{~g} 100 \mathrm{~g}^{-1}$ of dehydrated sweet cherry, $35 \mathrm{~g} 100 \mathrm{~g}^{1}$ of almond and $15 \mathrm{~g} 100 \mathrm{~g}^{1}$ of honey, and baked for $13 \mathrm{~min}$ at $120^{\circ} \mathrm{C}$.

Table 6 shows the nutritional composition of this formulation. The snack has a high content of fat (16.8 g $100 \mathrm{~g}^{1} ; 24.0 \%$ dietary reference intake, DRI), which came primarily from the almond; carbohydrates

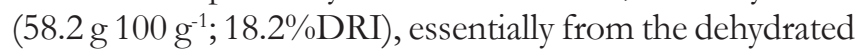
sweet cherry and from the honey; protein $\left(9.6 \mathrm{~g} 100 \mathrm{~g}^{1}\right.$; $17.5 \% \mathrm{DRI})$ and fibre $\left(3.9 \mathrm{~g} 100 \mathrm{~g}^{-1} ; 15.1 \% \mathrm{DRI}\right)$, both mainly from the almond. Additionally, the saturated fatty

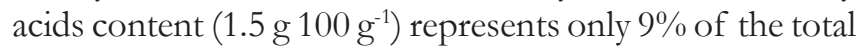

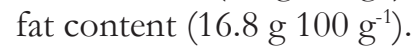

According to the EC Regulation $n^{\circ} 1924 / 2006$ (EC, 2006), the label of this snack could exhibit the following nutritional claims: "low saturated fat"; "with no added sugar"; "contains naturally occurring sugars"; "sodium free" or "salt free" and "source of fibre".

\section{CONCLUSIONS}

A new snack-bar formulation, based exclusively on sweet cherry, almond and honey, was developed and optimized through Response Surface Methodology and desirability function maximization. The optimal formulation, with $50 \mathrm{~g}$

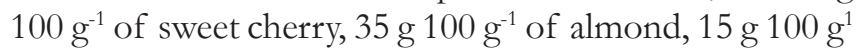
of honey and baked at $120^{\circ} \mathrm{C}$ for $13 \mathrm{~min}$, showed microbial stability due to its low water activity; a satisfactory microbial quality and a sensorial consumer acceptance. Furthermore, the nutrient analysis showed that the following claims could be printed in the label of this product: "low saturated fat"; "with no added sugar"; "contains naturally occurring sugars"; "sodium free" or "salt free" and "source of fibre".

\section{ACKNOWLEDGEMENTS}

We would like to acknowledge Dr. Isabel Lavado (Polytechnic Institute of Castelo Branco) for the English revision of the manuscript.

This work was supported by the project INNOACE, cofunded by the European Regional Development Fund (ERDF) through the INTERREG V-A Spain-Portugal (POCTEP) 2014-2020 Programme and CERNAS/IPCB FCT UID/AMB/00681/2013.

\section{Authors' contributions}

Cristina Miguel Pintado: conceptualization, methodology, supervision, writing - review and editing; Abel Veloso: data collection and analysis, writing - original draft; Zamira Maria: data collection and analysis, writing - original draft; Ana Silveira: laboratory analysis, data collection; Helena Beato: laboratory analysis, data collection; Luís Pinto de Andrade: supervision, writing - review and editing; Fernanda Delgado: conceptualization, supervision, methodology, writing - review and editing.

\section{REFERENCES}

AOAC. 1990. Official Methods of Analysis. $15^{\text {th }}$ ed. Association of Official Analytical Chemists, Washington, DC. 
AOAC. 2000. Official Methods of Analysis. $17^{\text {th }}$ ed. Association of Official Analytical Chemists, Gaithersburg, Maryland.

Baltrusaityte, V., P. R. Venskutonis and V. Ceksteryte. 2007. Radical scavenging activity of different floral origin honey and beebread phenolic extracts. Food Chem. 101: 502-514.

Brand-Williams, W., M. Cuvelier C. and Berset. 1995. Use of a free radical method to evaluate antioxidant activity. LWT. 28: 25-30.

Bucher, T., C. Collins, S. Diem and M. Siegrist. 2016. Adolescents' perception of the healthiness of snacks. Food Qual. Prefer. 50: 94-101.

Chaplin, K. and A. Smith. 2011. Definitions and perceptions of snacking. Nutraceutical Res. 9: 53-59.

Chua, L. S., N. L. A. Rahaman, N. A. Adnan and T. T. E. Tan. 2013. Antioxidant activity of three honey samples in relation with their biochemical components. J. Anal. Methods Chem. 2013: 313798.

Du, W., S. J. Abd, L. McCarthy and L. J. Harris. 2010. Reduction of Salmonella on inoculated almonds exposed to hot oil. J. Food Prod. 73: 1238-1246.

EC. 1996. Commission Regulation (EC) n 1107/96 of 12 June 1996. Official Journal of the European Communities L 148/1.

EC. 2006. Commission Regulation (EC) n 1924/2006 of 20 December 2006. Official Journal of the European Communities L 404/9.

EU. 2011. Regulation (EU) $n^{\circ} 1169 / 2011$ of 25 October 2011. Official Journal of the European Union $n^{\circ}$ L 304/18.

Escuredo, O., M. Míguez, M. Fernández-Gonzalez and M. C. Seijo. 2013. Nutritional value antioxidant activity of honeys produced in a European Atlantic area. Food Chem. 138: 851-856.

Ferreira, I. C. F., E. Aires, J. C. M. Barreira and L. M. Estevinho. 2009. Antioxidant activity of Portuguese honey samples: Different contributions of the entire honey and phenolic extract. Food Chem. 114: 1438-1443.

Gatenby, S. J. 1997. Eating frequency: Methodological and dietary aspects. Br. J. Nutr. 77: S7-S20.

Gilbert, R. J., J. Louvois, T. Donovan, C. Little, K. Nye, C. D. Ribeiro, J. Richards, D. Roberts and F. J. Bolton. 2000. Guidelines for the microbiological quality of some ready-to-eat foods sampled at the point of sale. Commun. Dis. Public Health. 3: 163-167.

Green, H., P. Siwajek and A. Roulin. 2017. Use of nutrient profiling to identify healthy versus unhealthy snack foods and whether they can be part of a healthy menu plan. J. Nutr. Intermed. Metab. 9: $1-5$.

Guiné, R. P. F., C. F. F. Almeida and P. M. R. Correia. 2014. Effect of packaging and conservation conditions on some physicalchemical properties of almonds. J. Hyg. Eng. Des. 8: 82-87.

ISO 4833-1:2013. 2013. Microbiology of the Food Chain Horizontal Method for the Enumeration of Microorganisms. Part 1: Colony Count at 30 Degrees $\mathrm{C}$ by the Pour Plate Technique. International Organization for Standardization, Geneva, Switzerland.

ISO 8589:2007/Amd 1. 2014. Sensory Analysis General Guidance for the Design of Test Rooms. International Organization for Standardization, Geneva, Switzerland.

Jan, K. N., P. S. Panesar and S. Singh. 2018. Optimization of antioxidant activity, textural and sensory characteristics of gluten-free cookies made from whole Indian quinoa flour. LWT Food Sci. Technol. 93: 573-582.

Kamil, A. and C. Y. O. Chen. 2012. Health benefits of almonds beyond cholesterol reduction. J. Agric. Food Chem. 60: 6694-6702.
Kant, A. K. and B. I. Graubard. 2015. 40-Year trends in meal and snack eating behaviors of American adults. J. Acad. Nutr. Diet. 115: $50-63$.

Kelley, D. S., Y. Adkins and K. D. Laugero. 2018. A review of the health benefits of cherries. Nutrients. 10: 368

Kiat, V. V., W. K. Siang, P. Madhavan, J. H. Chin, M. Ahmad and G. A. Akowauah. 2014. FT-IR profile and antiradical activity of dehulled kernels of apricot, almond and pumpkin. Res. J. Pharm. Biol. Chem. Sci. 5: 112-120.

Liu, Y., X. Liu, F. Zhong, R. Tian, K. Zhang, X. Zhang and T. Li. 2011. Comparative study of phenolic compounds and antioxidant activity in different species of cherries. J. Food Sci. 76: C633-C638.

Liu, Y., L. Luo, C. Liao, L. Chen, J. Wang and L. Zen. 2018. Effects of brewing conditions on the phytochemical composition, sensory qualities and antioxidant activity of green tea infusion: A study using response surface methodology. Food Chem. 269: 24-34.

Lloyd-Williams, F., M. Mwatsama, R. Ireland and S. Capwell. 2008. Small changes in snacking behaviour: the potential impact on CVD mortality. Public Health Nutr. 12: 871-876.

Mandalari, G., C. Nueno-Palop, G. Bisignano, M. S. J. Wickham and A. Narbad. 2008. Potential prebiotic properties of almond (Amygdalus communis L.) seeds. Appl. Environ. Microbiol. 74: 4264-4270.

Nath, A. and P. K. Chattopadhyay. 2007. Optimization of oven toasting for improving crispness and other quality attributes of ready to eat potato-soy snack using response surface methodology. J. Food Eng. 80: 1282-1292.

Olaitan, P.B., O. E. Adeleke and I. O. Ola. 2007. Honey: A reservoir for microorganisms and an inhibitory agent for microbes. Afr. Health Sci. 7: 65-159.

Pardhi, S. D., B. Singh, G. A. Nayik and B. N. Dar. 2017. Evaluation of functional properties of extruded snacks developed from brown rice grits by using response surface methodology. J. Saudi Soc. Agric. Sci. 18: 7-16.

Prvulovic, D., D. Malencic, M. Popovic, M. Ljubojevic and V. Ognjanov. 2011. Antioxidant properties of sweet cherries (Prunus avium L.) role of phenolic compounds. World Acad. Sci. Eng. Technol. 59: 1149-1152.

Ramesh, R., R. J. Shakil, B. Sivaraman, P. Ganesan and P. Velayutham. 2018. Optimization of the gelatinization conditions to improve the expansion and crispiness of fish crackers using RSM. LWT Food Sci. Technol. 89: 248-254.

Safe Food $360^{\circ}$. 2014. Water Activity (aw) in Foods. Available from: http://www.safefood360.com/resources/Water-Activity.pdf. [Last accessed on 2020 Nov 11].

Schmidt, S. J. and A. J. Fontana. 2007. Water activity values of selected food ingredients and products. In: G. V. BarbosaCánovas, A. J. Jr. Fontana, S. J. Schmidt and T. P. Labuza (Ed.), Water Activity in Foods Fundamentals and Applications, Blackwell Publishing, lowa, pp. 407-421.

Tapia, M. S., S. M., Alzamora and J. Chirife. 2007. Effects of water activity (aw) on microbial stability as a hurdle in food preservation. In: G. V. Barbosa-Cánovas, A. J. Jr. Fontana, S. J. Schmidt and T. P. Labuza (Ed.), Water Activity in Foods Fundamentals and Applications. Blackwell Publishing, lowa, pp. 239-272.

Usenik, V., J. Fabcic and F. Stampar. 2008. Sugars, organic acids, phenolic composition and antioxidant activity of Sweet cherry (Prunus avium L.). Food Chem. 107: 185-192. 